\title{
Role of TNF-alpha during central sensitization in preclinical studies
}

\author{
Pablo Andrade • Veerle Visser-Vandewalle • \\ Carolin Hoffmann · Harry W. M. Steinbusch • \\ Marc A. Daemen · Govert Hoogland
}

Received: 21 October 2010/Accepted: 20 April 2011/Published online: 11 May 2011

(C) The Author(s) 2011. This article is published with open access at Springerlink.com

\begin{abstract}
Tumor necrosis factor-alpha (TNF- $\alpha$ ) is a principal mediator in pro-inflammatory processes that involve necrosis, apoptosis and proliferation. Experimental and clinical evidence demonstrate that peripheral nerve injury results in activation and morphological changes of microglial cells in the spinal cord. These adjustments occur in order to initiate an inflammatory cascade in response to the damage. Between the agents involved in this reaction, $\mathrm{TNF}-\alpha$ is recognized as a key player in this process as it not only modulates lesion formation, but also because it is suggested to induce nociceptive signals. Nowadays, even though the function of TNF- $\alpha$ in inflammation and pain production seems to be generally accepted, diverse sources of literature point to different pathways and outcomes. In this review, we systematically searched and reviewed
\end{abstract}

P. Andrade $(\varangle) \cdot$ C. Hoffmann · H. W. M. Steinbusch .

G. Hoogland

Department of Neuroscience, Faculty of Health, Medicine and Life Sciences, Maastricht University, Universiteitssingel 50, Box 38, 6200 MD Maastricht, The Netherlands

e-mail: p.andrade@maastrichtuniversity.nl

P. Andrade · V. Visser-Vandewalle · G. Hoogland

Department of Neurosurgery, Mastricht University Medical

Center, Maastricht, The Netherlands

P. Andrade - V. Visser-Vandewalle · H. W. M. Steinbusch ·

G. Hoogland

European Graduate School of Neuroscience (EURON),

Maastricht, The Netherlands

V. Visser-Vandewalle

Maastricht Institute of Neuromodulative Development (MIND),

Maastricht, The Netherlands

M. A. Daemen

Department of Neurosurgery, Kliniek Klein Rosendael,

Rozendaal, The Netherlands original articles from the past 10 years on animal models of peripheral nervous injury describing TNF- $\alpha$ expression in neural tissue and pain behavior.

Keywords TNF- $\alpha \cdot$ Central sensitization $\cdot$ Neuropathic pain $\cdot$ Preclinical studies $\cdot$ Neuroinflammation

\section{Introduction}

Neuropathic pain (NP) is a chronic and extensive condition secondary to dysfunction or nerve damage, usually originated in the periphery. If the injurious stimulus perpetuates, dorsal horn neurons in the spinal cord become sensitized, enduring pain perception; process known as central sensitization (CS) [1-3]. Because inflammation is essential for NP development and that apoptosis is involved in CS, tumor necrosis factor-alpha (TNF- $\alpha$ ) becomes an interesting study target [4, 5]. Several studies have investigated the relation between TNF- $\alpha$ expression in different nervous tissues and pain behavior; hitherto these studies have not been conclusive. Though in general, TNF- $\alpha$ is associated with cellular harm and pain behavior, it has also been shown that these effects are bound by temporal and spatial resolutions.

For decades, animal models have reproduced cardinal aspects of human pain, offering essential features for the preclinical study of NP. The main classification of NP models divides them into central pain, peripheral nerve injury, and secondary disease neuropathy models. In this review, we will focus on the peripheral nerve injury models in order to study the effect of these lesions on the process of central sensitization. The primary anatomical structures involved in these injury procedures are the sciatic nerve and dorsal root ganglion (DRG). These methods comprise 
partial ligature, complete ligature, root or nerve pinching, crushing, transection, and local inflammatory stimulus. The most representative examples include the chronic constriction injury model (Bennett model), partial sciatic nerve ligation model (Seltzer model), spinal nerve ligation, plexus avulsion, compression of the DRG/root, laminectomy, and disc injury [6-12].

TNF- $\alpha$ is considered to be one of the principal mediators in pro-inflammatory processes that involve necrosis, apoptosis and proliferation [5, 13-15]. It is produced essentially by macrophages and T-lymphocytes in response to stressed or damaged tissue, and it may therefore serve as a systemic marker for tissue injury. For instance, complications found in inflammatory and autoimmune diseases are often accompanied by increased serum levels. In case of increased levels, a systemic inflammatory reaction leading to septic shock might occur. However, if TNF- $\alpha$ is present in low quantities it would generate a process responsible for local inflammatory symptoms, depending on the damaged structure [16-18]. In the nervous system, when a local peripheral injury is produced, it generates activation and morphological changes in dorsal horn microglia [19-23]. This process includes $\mathrm{P} 2 \mathrm{X} 4$ receptors activation, followed by $\mathrm{Ca}^{2+}$ influx and p38 MAPK activation. As a consequence, microglia releases diffusible factors like TNF- $\alpha$, modifying neuronal excitability and thereby pain perception [24-26]. TNF- $\alpha$ has two distinct receptors, TNF receptor1 (TNFR1 or p55) and TNF receptor-2 (TNFR2 or p75). The main effect of TNFR1 is related to apoptosis and is present in practically every cell; whereas TNFR2 has a limited constitutive expression and is basically associated with cell survival $[27,28]$. This is particularly important in pain attributable to different effects depending on specific receptor activation [29-31].

In this review, we present the functional and biochemical changes after peripheral nerve injury in animal models, focused on the role of TNF- $\alpha$ in the development of NP.

\section{Search methods}

Articles were collected via PubMed from 1999 until July 2010; in order to analyze the understanding progress in the last decade, a period with increased standardized methods since the initial works associating TNF- $\alpha$ and neuropathic pain were performed. The following keywords and their combinations were used: chronic neuropathic pain, tumor necrosis factor, dorsal horn apoptosis, central sensitization, peripheral nerve injury, and neuropathic pain model. The obtained citations were examined by two independent reviewers in order to assure the application of the inclusion and exclusion criteria.
The inclusion criteria were: original full-text articles, preclinical reports, written in English, quantitative data on inflammatory response and pain production, mechanical compression or irritation to neural tissue, involvement of peripheral nervous system injury, and detailed measurement instrument with objective examination protocol. The exclusion criteria comprised: omission of TNF- $\alpha$ levels measurements, absence of standardized behavioral evaluations, presence of co-morbidity, use of TNF- $\alpha$ as inductor of lesion or inflammatory procedure, trauma-related or spinal cord injury models, and involvement of other cytokines.

\section{Results}

From the primary search a total of 2,896 publications were identified. Based on titles and abstracts, 2,814 articles were discarded due to irrelevance to the topic or duplication between different combinations. From the 82 prospective studies, 73 were selected according to the inclusion criteria. After applying the exclusion criteria we obtained 33 articles that were finally chosen for this review (Fig. 1) [32-64].

From these 33 studies, 25 used rats of different strains and 8 applied genetically modified mice. The sample size of the experiments ranged from 7 to 360 animals, with a mean of 77 rodents per study. The most reproduced model

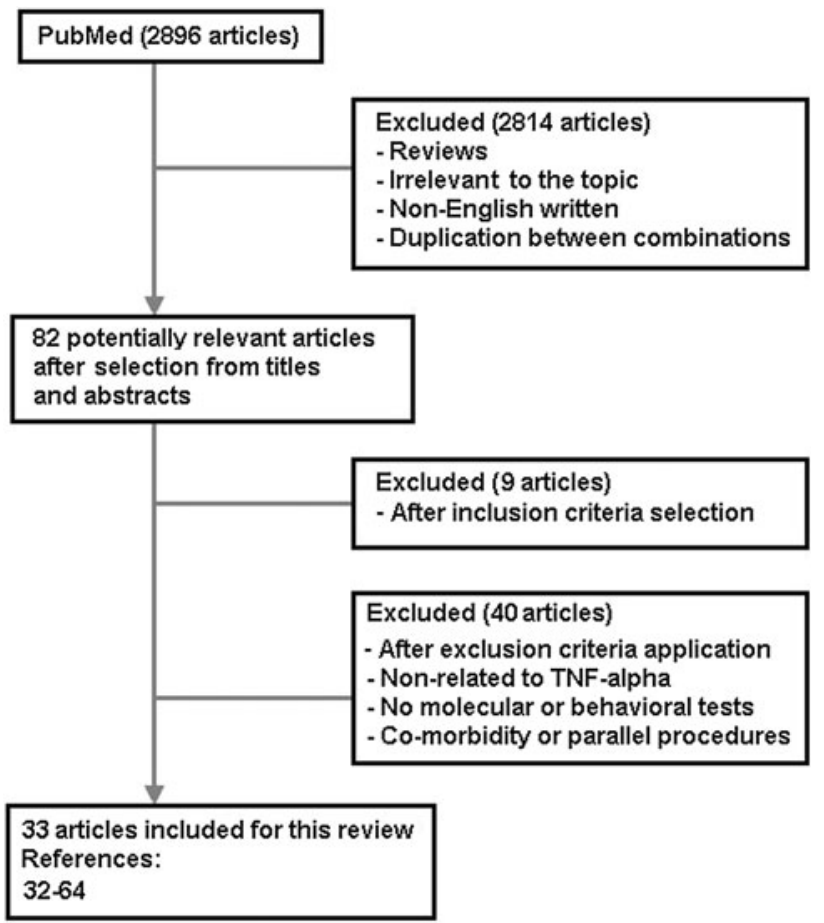

Fig. 1 Flow diagram representative of search strategy, identification, inclusion and exclusion of articles 
was the ligation of the sciatic nerve denominated chronic constriction injury $(n=14)$, followed by nerve crushing $(n=8)$ and nerve transection $(n=4)$. The most common location to induce the inflammatory process was the sciatic nerve $(n=18)$ followed by the spinal nerves $(n=5)$. Tissue samples were obtained from diverse structures, mostly the DRG $(n=16)$, sciatic nerve $(n=13)$ and spinal cord ( $n=10$ ) (Table 1$)$. Laboratory techniques used for TNF- $\alpha$ determination in these biopsies included primarily immunohistochemistry $(n=22)$, and secondary ELISA $(n=8)$, qPCR $(n=7)$, and immunoblotting $(n=5)$. Follow-up of pain behavior monitoring ranged from 5 days to 12 weeks, 14 days being the most repeated period $(n=11)$. Not all of the included studies in this review applied behavioral testing related to allodynia and hyperalgesia ( $n=11)$; the rest assessed mechanical sensitive thresholds primarily with von Frey filaments ( $n=18$ ), and thermal responsiveness with the Hargreaves test $(n=10)$. Some other conduct assessment techniques comprising hot-plate $(n=2)$ and Randall-Selitto tests $(n=2)$.

Mechanical allodynia was assessed in 20 studies through application of pressure in affected and non-affected limbs in order to evaluate painful responses. Each one of these studies showed a significant decrease in all cases in nociceptive thresholds as a consequence of the injury procedure when compared to sham groups. Initiation of pain typically started $24 \mathrm{~h}$ after the lesion intervention, reached maximum levels at 1-2 weeks, and returned close to presurgical control levels after 4 weeks. In two reports bilateral allodynia was present, in one case only for 7 days and referred in the second one as significant and long-lasting [42, 64]. Nine articles evaluated pharmacotherapy and found the highest effectiveness when the drugs were applied within 7 days after injury. In a specific case of cannabinoid administration, an antinociceptive effect was achieved after applying high doses from day 7 to 14 after injury (20 mg/kg) [36]. Opioid administration also reverted successfully the acute nociceptive effects, but only at increased doses and tolerance development $(10 \mathrm{mg} / \mathrm{kg}$ b.i.d. for 5 days) [55].

Thermal hyperalgesia followed a similar pattern as mechanical allodynia, showing lower thresholds at shortterm measurements, starting to decrease and even reaching baseline levels after 14 days. In one article TNFR1-deficient rodents did not exhibit significant painful behavior after heating stimulation at any time point after injury [63] (Table 2).

All models show increased $\mathrm{TNF}-\alpha$ levels after injury. Pharmacological treatments that failed to decrease these levels included monotherapy of paracetamol, tramadol, cannabidiol, morphine, soluble TNF receptor, and IL-1 receptor antagonist. On the other hand, successful interventions that lower TNF- $\alpha$ expression included NMDA receptor antagonist MK-801, thalidomide, combined therapy of soluble TNF receptor with IL-1 receptor antagonist, chronic administration of morphine (dosedependant with aggravation after interruption), $\alpha 2$-macroglobulin, nimesulide, a combination of paracetamol with tramadol, recombinant human erythropoietin and triamcinolone [32, 34-36, 43, 45, 55, 61, 62, 64].

Chronologically, TNF- $\alpha$ expression was characterized by an immediate increase in affected structures starting as soon as $1 \mathrm{~h}$ after injury [45, 56, 59]. Peak levels are detected around $24 \mathrm{~h}$, sustain for about 3 days, and in many cases then decreased, occasionally to baseline levels [40, 41, 45, 47]. Some publications describe a lowering of $\mathrm{TNF}-\alpha$ expression after this point, but the mainstream pointed out the maintenance of a plateau phase up to 1-2 weeks, followed by a periodical decline. Measurements performed at 3 and 4 weeks reveal weak signaling of the inflammatory process $[37,39-41,45,47,54,56,59$, 60]. Only one study documented prolonged increased TNF$\alpha$ levels lasting at least 6 and 12 weeks, not only in nervous tissue but also in connective tissue, after applying the high force reaching task model [39].

The degree to which an altered TNFR1 and TNFR2 ratio contributes to pain behavior is still not clear. One study observed an increased TNFR1 expression several days after dorsal root lesion, while TNFR2 levels remained unchanged [44]. In contrast, a similar follow-up after sciatic nerve injury resulted in a twofold increased TNFR1 level and a sevenfold elevated TNFR2 level [41]. Yet another report showed that immediate measurement only after $6 \mathrm{~h}$ postspinal nerve ligation revealed that both receptors showed similar increased expression in the dorsal root ganglia and remained at comparable levels up to the maximum followup [59].

\section{Discussion}

In this review we have summarized the reports that appeared over the past 10 years and described peripheral injury-induced TNF- $\alpha$ expression in the nervous tissue and its role in the production of CS. To date, there is a considerable amount of evidence to support the hypothesis that inflammatory process following tissue damage can lower pain thresholds. In this respect, many pathways and cytokines have been described to contribute in the development of chronic nociceptive signaling, including the three proinflammatory cytokines that induce activation of p38 MAPK: TNF- $\alpha$, IL- $1 \beta$ and IL-6 [25]. Focus on TNF- $\alpha$ is because it is regarded as the archetypical proinflammatory agent, attributable to its function as an inductor of diverse processes that initiate and perpetuate the inflammatory 


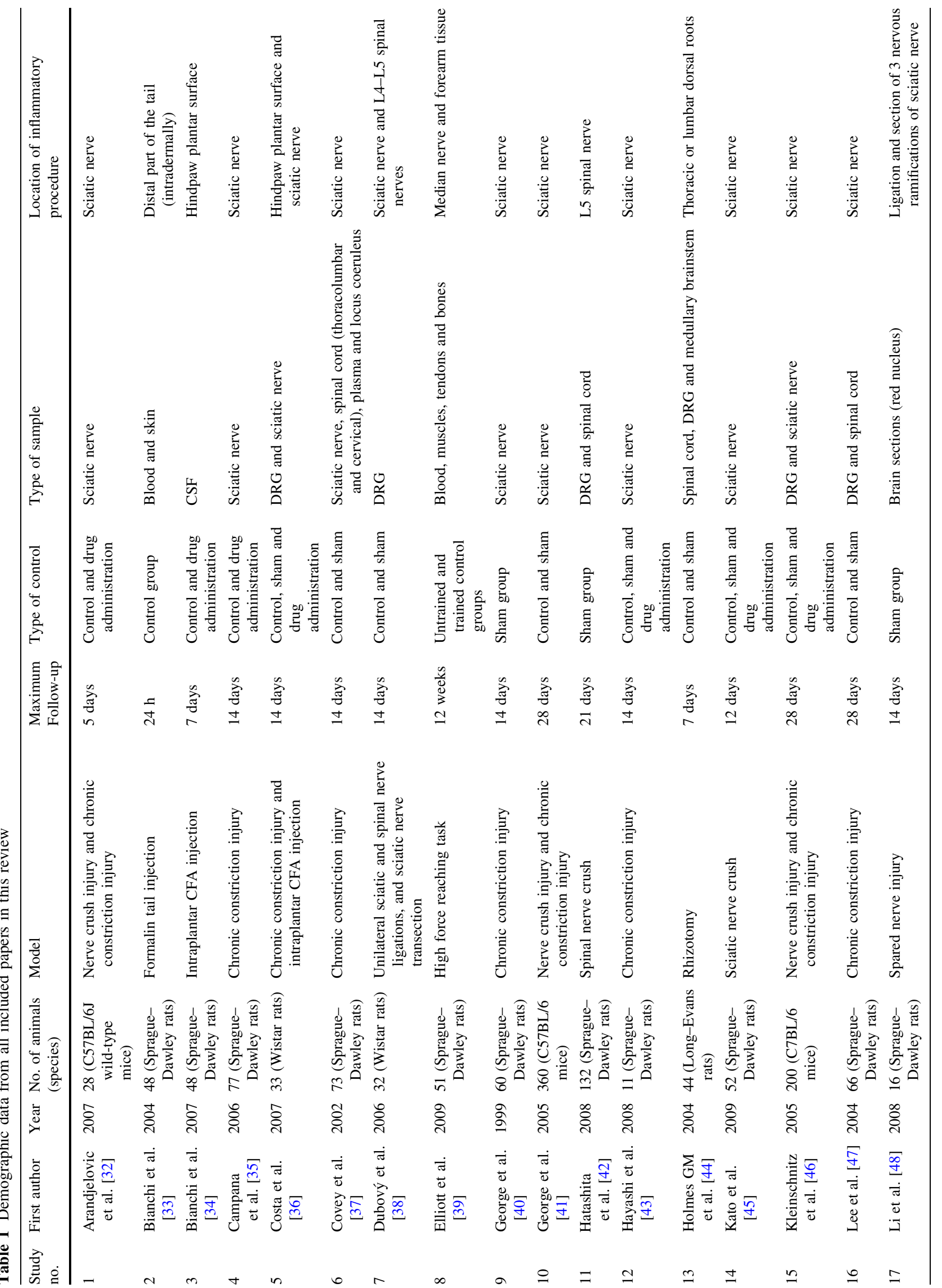




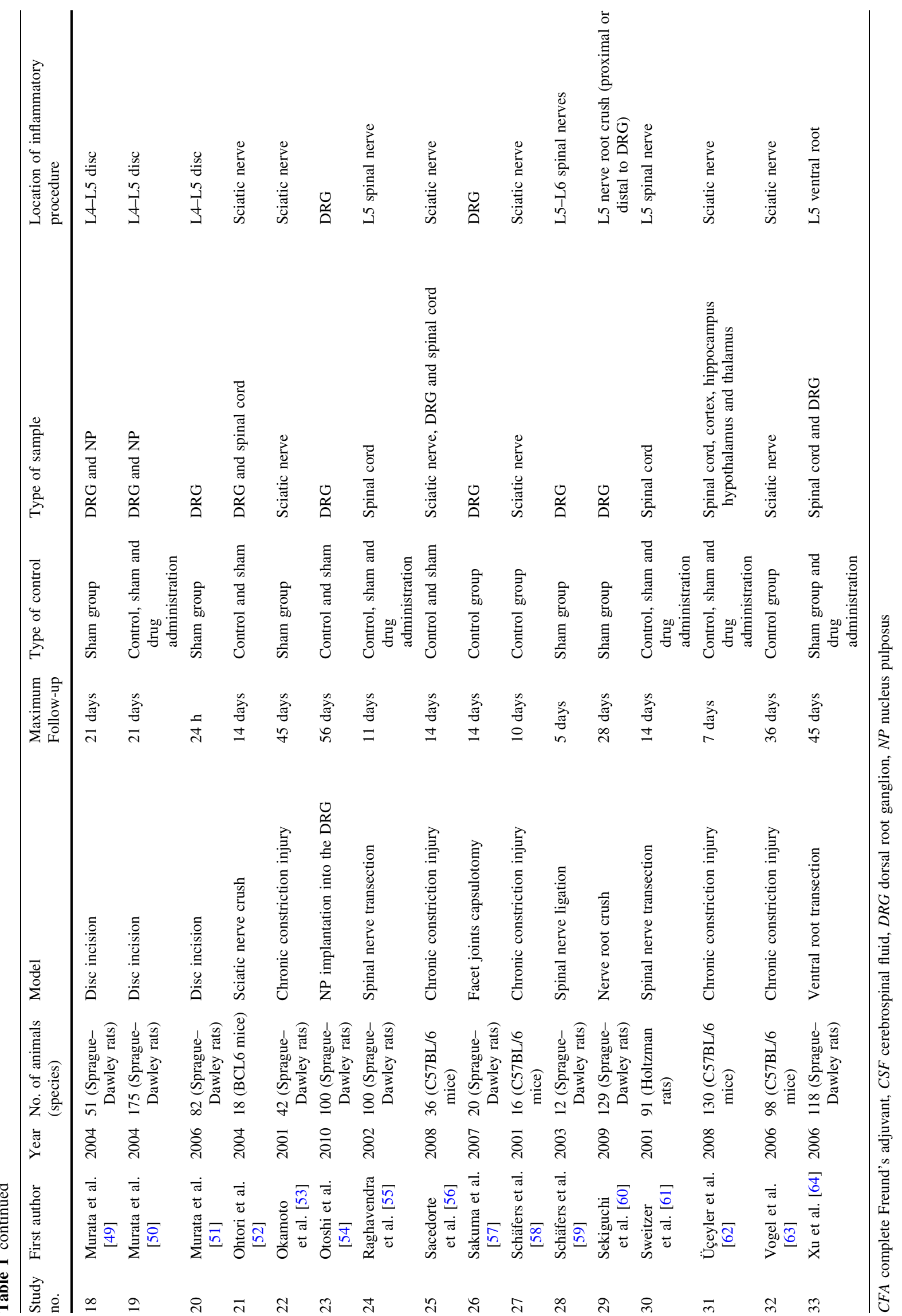


Table 2 Detection methods to asses TNF-alpha expression and behavioral tests to measure pain

Study TNF detection method and $\quad$ TNF- $\alpha$ levels $\quad$ Pain behavioral data

no. behavioral test

1 Immunohistochemistry and qPCR

ELISA and Hargreaves test

ELISA and Randall-Selitto paw-withdrawal test

Immunohistochemistry, histology, qPCR, von Frey filaments and Hargreaves test

ELISA, Randall-Selitto pawwithdrawal test and Hargreaves test

Immunohistochemistry, in situ hybridization, bioassay and hot-plate test

ELISA and von Frey filaments

Immunohistochemistry, Immunoblotting and ELISA

ELISA, von Frey filaments and Hargreaves test

11 Immunohistochemistry, immunoblotting and von Frey filaments

\section{Ninefold increase of TNF- $\alpha$ mRNA in control None animals. $\alpha 2$-macroglobulin activated for cytokine binding decreases levels of mRNA expression after injection}

Significant increase of TNF- $\alpha$ levels in the hindpaw Sign and forepaw at all time-points compared with control animals after formalin injection

TNF- $\alpha$ levels significantly increased in non-treated animals. TNF- $\alpha$ concentrations prevented with nimesulide or paracetamol and tramadol combined, but not by paracetamol and tramadol used independently

TNF- $\alpha$ was present in endoneurial cells, including macrophages, axons and Schwann cells cytoplasm in non-treated animals. rhEpo decreased TNF- $\alpha$ mRNA at injury site, and also decreased the extent of nerve degeneration

Increased TNF- $\alpha$ levels were present in injured DRG when compared to sham, but no changes in injured sciatic nerve rats. High doses of cannabidiol did not modified the elevated levels present in DRG samples

Increased TNF- $\alpha$ levels in sciatic nerve until day 14 , and dissipated after that, with unchanged levels in contralateral nerve; thoracolumbar spinal cord showed elevated TNF- $\alpha$ levels; no elevation in cervical spinal cord; significant accumulation increase of mRNA specific for TNF- $\alpha$ in locus coeruleus

Increased TNF- $\alpha$ levels in neuronal bodies and satellite cells compared to control and sham rats (ipsi- and contralateral, but higher in contralateral side). Levels reached highest peak 1 week after surgery, decreasing after 2 weeks; with TNFR1 expression ipsi- and contralateral after 2 weeks

Increased TNF- $\alpha$ levels at week 6 , but not significant at week 12 in serum. High levels detected in distal bone at week 12 after repetitive task performance

TNF- $\alpha$ levels increased rapidly after CCI with highest peak at $12 \mathrm{~h}$, up to day 3 . Rapid increase of endoneurial TNF with plateau phase back to baseline on day 14

TNF was increased on day 1 and 3 after injury (CCI and crush) but it was not detectable on day 7 or after. TNFR1 increased twofold between days 1 and 7; and TNFR2 elevated sevenfold on days 3 and 7

TNF- $\alpha$ expression in the contralateral DRG significantly increased from day 7 to 21
Significant hyperalgesic hindpaw response after formalin administration, but not in the forepaw

Significant decrease of nociceptive thresholds in non-treated animals. Mechanical allodynia was prevented by oral administration of nimesulide, tramadol and paracetamol

Significant mechanical allodynia and thermal hyperalgesia increased in non-treated group, but significantly decreased after rhEpo administration

Significant increase in mechanical and thermal hyperalgesia in non-treated group; attenuated both by cannabidiol, but with dose-dependent behavior and only after using high doses

Significant decrease of paw-withdrawal latency when compared to sham and control, with highest value on day 12 and return to baseline levels on day 14

None

Withdrawal threshold decreased progressively at weeks 6 and 12 for cutaneous sensitivity and grip strength at week 12

None

Thermal hyperalgesia and mechanical allodynia are present in both CCI and crush; thermal sensitivity maximum peak on week 2 , and mechanical allodynia throughout all measures

Ipsilateral withdrawal threshold was significantly decreased for 21 days; contralateral threshold decreased also, but for 7 days 
Table 2 continued

\begin{tabular}{|c|c|c|c|}
\hline $\begin{array}{l}\text { Study } \\
\text { no. }\end{array}$ & $\begin{array}{l}\text { TNF detection method and } \\
\text { behavioral test }\end{array}$ & TNF- $\alpha$ levels & Pain behavioral data \\
\hline 12 & $\begin{array}{l}\text { Immunohistochemistry, von } \\
\text { Frey filaments, hot-plate test, } \\
\text { pin-prick test and acetone drop } \\
\text { test }\end{array}$ & $\begin{array}{l}\text { TNF- } \alpha \text { staining was significantly increased after } \\
\text { injury; especially prominent in Schwann cells } \\
\text { and cells with cytological mast cells } \\
\text { characteristics. TNF } \alpha \text {-positive mast cells } \\
\text { significant reduction after triamcinolone } \\
\text { administration }\end{array}$ & $\begin{array}{l}\text { Significant increase in heat-hyperalgesia, } \\
\text { mechano- and cold-allodynia throughout the } \\
\text { tests. Triamcinolone had a significant reduction } \\
\text { on mechanical allodynia and thermal } \\
\text { hyperalgesia }\end{array}$ \\
\hline 13 & $\begin{array}{l}\text { Immunohistochemistry and } \\
\text { histology }\end{array}$ & $\begin{array}{l}\text { Presence of constitutive TNFR1 on DRG, spinal } \\
\text { afferences, solitary tract, vagal and spinal } \\
\text { trigeminal tract in naive and operated animals. } \\
\text { No TNFR2 shown in the solitary tract or dorsal } \\
\text { horn afferences. }\end{array}$ & None \\
\hline 14 & $\begin{array}{l}\text { Immunohistochemistry, } \\
\text { immunoblotting and von Frey } \\
\text { filaments }\end{array}$ & $\begin{array}{l}1 \mathrm{~h} \text { after the injury, TNF immunoreactivity was } \\
\text { shown in Schwann cells, endothelial cells, } \\
\text { fibroblasts and intact axons. Increasing }\end{array}$ & $\begin{array}{l}\text { Mechanical hyperalgesia was detected from } 6 \text { to } \\
12 \text { days after injury. Etanercept inhibited pain } \\
\text { related behaviors significantly }\end{array}$ \\
\hline
\end{tabular}

$15 \quad$ qPCR very weak activity.

TNF- $\alpha$ levels remained unchanged in None contralateral nerves. Significant ipsilateral increase at day 3 in TNF- $\alpha$ levels

16 qPCR, von Frey filaments and Hargreaves test

TNF- $\alpha$, TNFR1 and TNFR2 mRNA levels in ipsilateral DRG increased significantly after 1 day post-injury, levels decreased after day 1 , and returned to baseline on days 7 and 14; in the spinal cord the maximal level of TNF- $\alpha$ and TNFR1 was reached on day 3 , and also decreased to baseline at days 7 and 14

17 Immunohistochemistry and von Frey filaments

Significantly higher TNF- $\alpha$ cells and average staining intensity compared to sham

Significantly higher cells in disc incision group compared to sham

18 Immunohistochemistry

19 Immunohistochemistry and histology

20 Immunohistochemistry and electron microscopy

21 Immunohistochemistry

qPCR, von Frey filaments and Hargreaves test

23 Immunohistochemistry, immunoblotting and von Frey filaments

Immunohistochemistry, ELISA, von Frey filaments and tailflick test Hargreaves test
Significant increase of TNF- $\alpha$ immunoreactive cells between day 1 and 3, medium levels at days 7 and 14, and very decreased on day 21 . No cells found after TNF- $\alpha$ inhibitor treatment at any time point

Significant increase pixels in endoneurium and inflammatory crescent

Weak to moderate immunoreactivity in DRG when compared to non-lesion groups. Increased immunoreactivity in spinal cord with its highest peak after 5 days

Gene expression statistical significance only at day 14

Immunohistochemistry colocalized TNF- $\alpha$ with endoneurial macrophages and GFAP-IR glial cells. Immunoblotting showed significant expression on day 7 in the NP group, but any difference at day 28

High amounts of cytokines and mRNA expression after spinal nerve transection, with no effect of acute morphine administration, tolerance with chronic treatment and worsening with withdrawal

High levels of mRNA in the sciatic nerve at 6 and $24 \mathrm{~h}$; in DRG at 24 and $72 \mathrm{~h}$; and no expression at any moment in spinal cord
Mechanical allodynia increased significantly

1 day after injury with maximum levels at day

7. Thermal hyperalgesia had its peak at day 3 . Both persisted for at least 28 days

Threshold significantly reduced when compared to sham group

None

None

None

None

CCI group showed reduced sensory threshold for thermal and mechanical allodynia (mainly at short-term periods)

Threshold significantly reduced in NP group with lowest point at day 14 , with gradual increase after it

Significant increase of allodynia in both tests, reverted effect in both with opioids application (high doses)

CCI group showed reduced sensory threshold for thermal and mechanical allodynia (lowest point at day 14) 
Table 2 continued

\begin{tabular}{|c|c|c|}
\hline $\begin{array}{l}\text { Study } \\
\text { no. }\end{array}$ & $\begin{array}{l}\text { TNF detection method and } \\
\text { behavioral test }\end{array}$ & TNF- $\alpha$ levels \\
\hline 26 & Immunohistochemistry & $\begin{array}{l}\text { Weak cell expression of TNFR1 in non-injured } \\
\text { neurons; elevated immunoreactivity for TNFR1 } \\
\text { in injured neurons. Higher receptor expression in } \\
\text { higher levels of DRGs compared to lower spina } \\
\text { levels. }\end{array}$ \\
\hline 27 & $\begin{array}{l}\text { Immunohistochemistry, von } \\
\text { Frey filaments and } \\
\text { Hargreaves test }\end{array}$ & $\begin{array}{l}\text { Immunohistochemistry showed no statistical } \\
\text { differences between treated and untreated } \\
\text { animals after } 10 \text { days (no differences between } \\
\text { treatments) }\end{array}$ \\
\hline
\end{tabular}

in stainings and von Frey filaments

qPCR von Frey filaments, Hargreaves test and cold sensitivity test

\section{None}

(n)

Significant increase of mechanical and thermal allodynia in CCI group (anti-TNF Ab reduces thermal hyperalgesia)

Significant mechanical allodynia showed in ligated animals when compared to sham, starting at $6 \mathrm{~h}$ with a peak at $24 \mathrm{~h}$

\section{At day 14 proximal and distal crush groups} showed reduced thresholds; at day 28 only the distal crush group showed significant mechanical allodynia

Significant increase of allodynia in saline treated rats, high response rate when treated with sTNFR spinal cord of all animals, any treatment showe to be effective to change these findings

None

mRNA was detectable in controls in all studied tissues. Gene expression decreased within the first $6 \mathrm{~h}$ after surgery in all areas. NMDA receptor antagonist inhibited early gene expression decrease

TNFR1(-) mice showed significant increase of intact axons on day 36 compared to wild-type mice. Maximal significant edema was found on day 3 in TNFR2(-) mice, but also the lowest significant level at day 15 in this same group. No differences found in number of macrophages and degenerating fibers

Significant increase in immunoreactivity cells of TNF- $\alpha$ and TNFR1 in ipsilateral DRG compared to sham; and increased expression of TNF- $\alpha$ and TNFR1 bilaterally in dorsal and ventral horn of the spine. Significant decrease in immunoreactivity was found in DRG and spinal cord after thalidomide injection at any time point of evaluation after surgery
TNFR1(-) mice did not develop heat allodynia. TNFR1(-) and TNFR2(-) mice showed decreased mechanical and cold hyperalgesia; and less changes in skin temperature

Significant and long-lasting bilateral mechanical allodynia and thermal hyperalgesia in transection group. Thalidomide injection attenuated both types of allodynia when it was applied in the first 7 days post-surgery

CCI chronic constriction injury, rhEpo recombinant human erythropoietin, $D R G$ dorsal root ganglion, $N P$ nucleus pulposus, $s T N F R$ soluble TNF receptor, TNFR1(-) deficient TNF receptor 1, TNFR2(-) deficient TNF receptor 2, TNFR1 TNF receptor 1, TNFR2 TNF receptor 2, GFAP-IR glial fibrillary acidic protein-immunoreactive

response. At the same time, its increased expression in nervous tissues upon a pain stimulus suggests that this cytokine is essential for the development of pain sensation [65-69].

Several authors published similar results with regard to $\mathrm{TNF}-\alpha$ presence in peripheral and central nervous tissue after neural injury (Fig. 2). However, part of the main divergences remains in the involvement and interactions of
TNFR1 and TNFR2. Thus far, it seems that both receptor types play a different role in the development of allodynia and hyperalgesia depending on the site of the lesion and the moment of the cascade activation. For example, TNFR1 has shown constitutive expression in the uninjured spinal cord in modulatory centers like the dorsal horn, whereas these areas hardly express TNFR2 [44, 70]. Nevertheless, this does not imply that after peripheral nerve injury and 

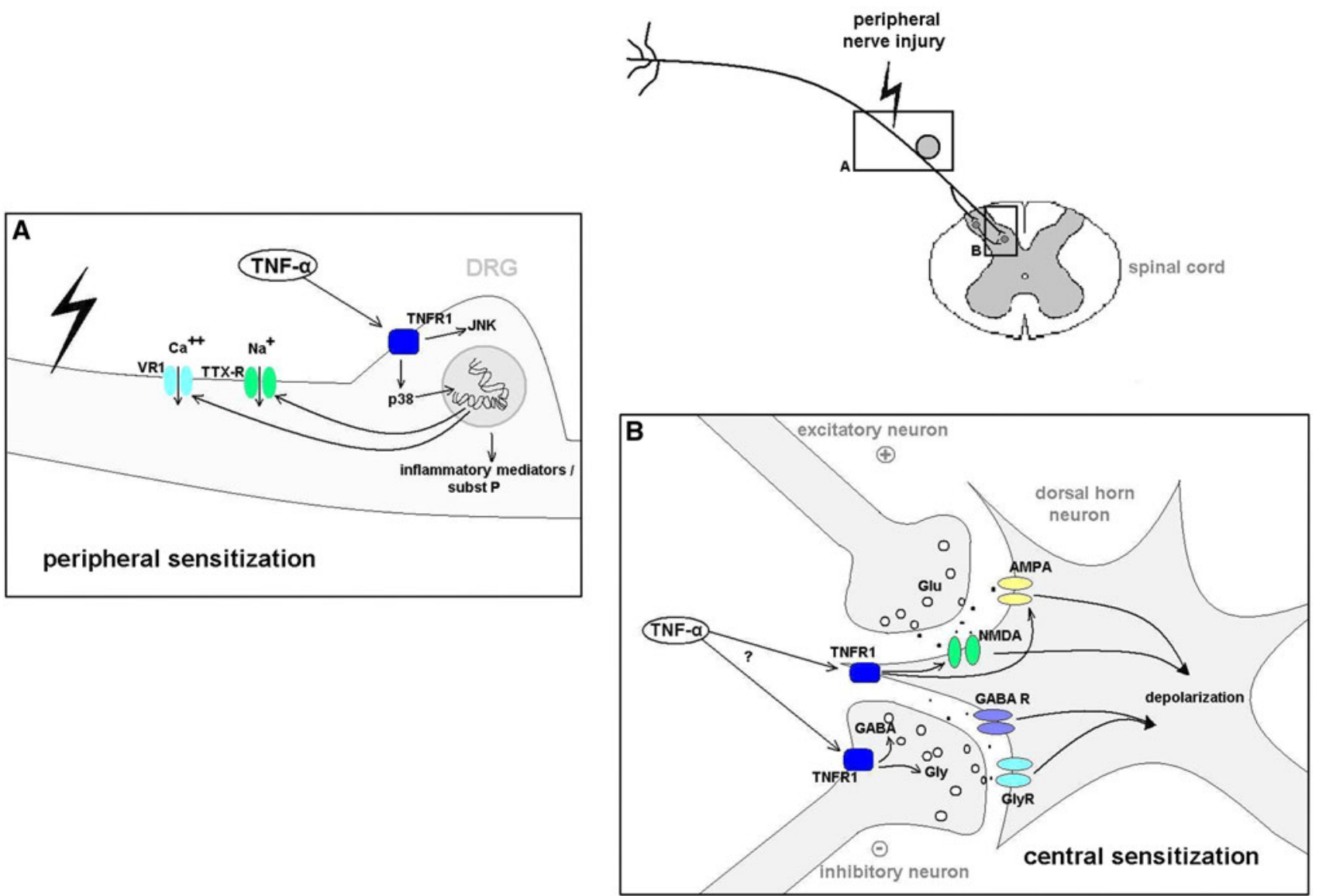

Fig. 2 Mechanisms involved in pain. TNF- $\alpha$ increases hyperexcitability and consequently neuropathic pain via different peripheral and central mechanisms. At the site of injury TNF- $\alpha$ leads to activation of p38 and JNK, followed by increased TTX-R and VR1 expression, accompanied by production of other inflammatory agents and substance P. In the dorsal horn of the spinal cord, TNF- $\alpha$ induces

TNF- $\alpha$ release, TNFR2 could not be involved in nociceptive regulation [47]. This could also be dependant on the proximity of these lesions from the spinal cord, illustrated by earlier manifestation of pain in spinal nerve lesions (h) than in sciatic nerve lesions (days) $[45,59]$. In judgment of the literature reported to our days, it is not still clear if the final nociceptive outcome is more dependant on the amount of cytokine or on the activation/inhibition of specific receptors (Fig. 3).

The increase of TNF- $\alpha$ immunoreactive cells or mRNA levels showed a similar temporal resolution, regardless of the studied tissue or injury model. As previously described, TNF- $\alpha$ production typically starts to reach maximal levels within $24 \mathrm{~h}$, which are maintained for over 2 weeks and then usually drop $[37,39-41,45,47,54,56,59,60]$. This paradigm is important for understanding the development of painful symptomatology and for the therapeutic timing approach. Behavioral data show that the clinical increased activity of NMDA and AMPA receptors, leading to depolarization. It is not completely elucidated yet the role of TNF- $\alpha$ on inhibitory neurons, but it is suggested that it increases GABA and glycine release from presynaptic terminals, producing hyperexcitability

presentation follows the presence of increased amounts of TNF- $\alpha$ in neural tissue [71-73]. Fluctuation in TNF- $\alpha$ levels tended to match with increased or decreased states of mechanical allodynia and thermal hyperalgesia. Progressive nociception in injured animals was established after the first few days and maintained until its highest point around the second week, followed by a gradual drop up to baseline thresholds $[37,54,56]$. This transient pain behavior may be a consequence of the continuous adaptation of pain perception that familiarizes the animal with the applied stimuli, yet in each study the cytokine levels correlated closely to the pain sensation [41, 53]. In this respect, TNF- $\alpha$ involvement in pain could also be inferred in studies where wild-type mice showed greater levels of pain when compared to genetically TNF knock-out animals $[74,75]$.

The pharmacological therapies proved to be successful when applied during the first 7 days post-lesion, which is 
Fig. 3 Intracellular pathways related to TNFR1 and TNFR2. On the left, TNFR1 is primarily related to the induction of apoptosis; though, it can interact via TRAF2 to promote cell survival under certain circumstances. On the right, TNFR2 function is oriented to follow parallel pathways that will lead to cell survival and proliferation. Probably the balance and interaction between these two receptors determine the final damage produced by lesions, and therefore the amount of pain

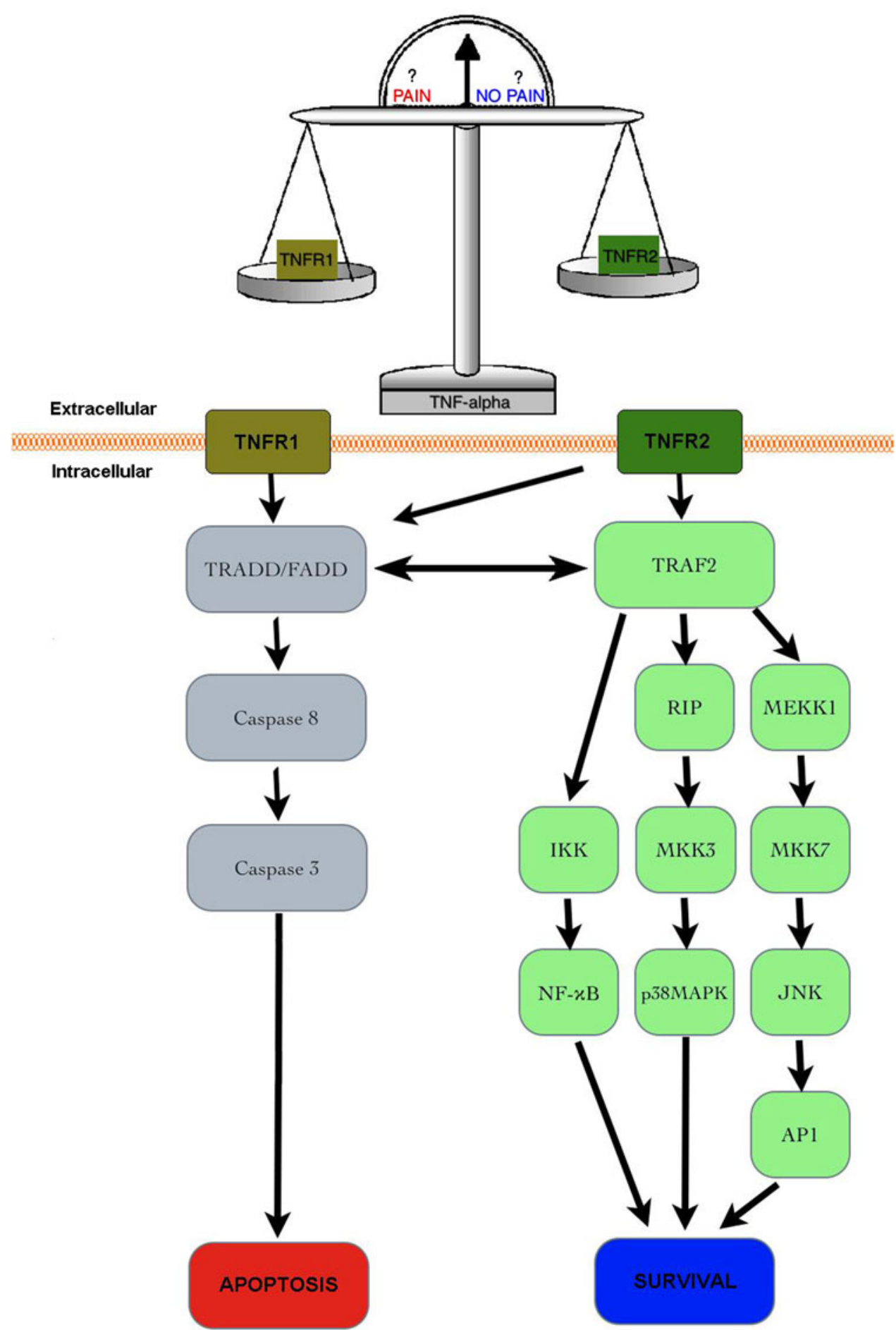

consistent with the temporal resolution of TNF- $\alpha$ expression, probably avoiding the initial inflammatory response $[66,76]$. This is also an essential matter in the apparent dual intervention of TNF- $\alpha$ in neurons as toxic or protective agent. Originally, the function of this cytokine has been described as harmful, but previous evidence and data in this review suggest that protection and regeneration could be involved in a receptor-dependant mode. It has been described that TNFR2 has a fundamental participation in remyelination of neurons after injury, probably linked to its late participation in the inflammatory cascade [44, 70, 77-79]. This suggestion also comes from delayed expression of TNFR2, which coincides with behavioral recovery in the late phases of pain sensation. Thus, it is of vital 
importance to understand the temporal expression of TNF$\alpha$ and its receptors in order to develop a successful therapeutic strategy. In these days, we can observe that the same cytokine at different moments, acting on different receptors, could bring opposite histological and clinical outcomes. These observations bring the query as to which factors are more determinant for the production of pain, the concentration of TNF- $\alpha$ or the TNFR1-TNFR 2 expression ratio. In this respect, a key question that remains is why patients with chronic NP do not benefit from this selflimiting protective mechanism. We believe that a balance alteration between the TNF- $\alpha$ receptors could determine the severity of pain, not only in a temporal expression (acute or chronic) but also on the extension of the produced damage. Animal models have proven to develop and reproduce pain in a comparable manner to human observations. In summary, there is evidence from physical injury models, transgenic models, and pharmacological interference studies that TNF$\alpha$ expression in the spinal cord modulates pain sensation. However, future perspectives for treatment still require better understanding of its receptors and intracellular pathway interactions as pain modulators. Therefore, further translational studies may be performed to address this challenging topic and design more effective therapies by regulating inflammation-induced pain sensation.

Acknowledgments We would like to thank the support from the Netherlands Organization for Scientific Research (NWO) (VENI 916.76.042)

Open Access This article is distributed under the terms of the Creative Commons Attribution Noncommercial License which permits any noncommercial use, distribution, and reproduction in any medium, provided the original author(s) and source are credited.

\section{Appendix I}

Table of excluded studies $(n=40)$

\begin{tabular}{lll}
\hline $\begin{array}{l}\text { Study } \\
\text { No. }\end{array}$ & Reference & $\begin{array}{l}\text { Exclusion } \\
\text { reason }\end{array}$ \\
\hline 1 & $\begin{array}{l}\text { Carlton SM, Du J, Tan HY et al. (2009) } \\
\text { Peripheral and central sensitization in remote } \\
\text { spinal cord regions contribute to central } \\
\text { neuropathic pain after spinal cord injury. Pain } \\
\\
\text { 147:265-276 }\end{array}$ & I \\
& Chew DJ, Leinster VH, Sakthithasan M et al. & I \\
& (2008) Cell death after dorsal root injury. & \\
& Neurosci Lett 433:231-234 & \\
& Czeschik JC, Hagenacker T, Schäfers M et al. I \\
& (2008) TNF-alpha differentially modulates \\
& ion channels of nociceptive neurons. Neurosci \\
& Lett 434:293-298
\end{tabular}

Appendix continued

Study Reference

Exclusion

No.

reason

4 DeLeo JA, Colburn RW, Rickman AJ (1997) III Cytokine and growth factor immunohistochemical spinal profiles in two animal models of mononeuropathy. Brain Res 759:50-57

5 DeLeo JA, Rutkowski MD, Stalder AK et al. I (2000) Transgenic expression of TNF by astrocytes increases mechanical allodynia in a mouse neuropathy model. Neuroreport 11:599-602

6 de Novellis V, Siniscalco D, Galderisi U et al. I (2004) Blockade of glutamate mGlu5 receptors in a rat model of neuropathic pain prevents early over-expression of proapoptotic genes and morphological changes in dorsal horn lamina II. Neuropharmacology 46:468-479

7 Deumens R, Jaken RJ, Knaepen L et al. (2009) I Inverse relation between intensity of GFAP expression in the substantia gelatinosa and degree of chronic mechanical allodynia. Neurosci Lett 452:101-105

8 Gustafson-Vickers SL, Lu VB, Lai AY et al. (2008) Long-term actions of interleukin-1beta on delay and tonic firing neurons in rat superficial dorsal horn and their relevance to central sensitization. Mol Pain 4:63

Ignatowski TA, Covey WC, Knight PR et al. I (1999) Brain-derived TNF alpha mediates neuropathic pain. Brain Res 841:70-77

10 Ignatowski TA, Sud R, Reynolds JL et al. (2005) The dissipation of neuropathic pain paradoxically involves the presence of tumor necrosis factor-alpha (TNF). Neuropharmacology 48:448-460

11 Jaken RJ, Joosten EA, Knüwer M et al. (2010) II Synaptic plasticity in the substantia gelatinosa in a model of chronic neuropathic pain. Neurosci Lett 469:30-33

12 Jiang YQ, Xing GG, Wang SL et al. (2008) Axonal accumulation of hyperpolarizationactivated cyclic nucleotide-gated cation channels contributes to mechanical allodynia after peripheral nerve injury in rat. Pain 137:495-506

13 Kawamura T, Akira T, Watanabe $\mathrm{M}$ et al. (1997) Prostaglandin E1 prevents apoptotic cell death in superficial dorsal horn of rat spinal cord. Neuropharmacology 36:1023-1030

14 Kawasaki Y, Zhang L, Cheng JK et al. (2008) I, IV Cytokine mechanisms of central sensitization: distinct and overlapping role of interleukin1 beta, interleukin-6, and tumor necrosis factor-alpha in regulating synaptic and neuronal activity in the superficial spinal cord. J Neurosci 28:5189-5194 
Appendix continued

\begin{tabular}{lll}
\hline $\begin{array}{l}\text { Study } \\
\text { No. }\end{array}$ & Reference & $\begin{array}{l}\text { Exclusion } \\
\text { reason }\end{array}$ \\
\hline 15 & $\begin{array}{l}\text { Kunz S, Tegeder I, Coste O et al. (2005) } \\
\text { Comparative proteomic analysis of the rat } \\
\text { spinal cord in inflammatory and neuropathic } \\
\text { pain models. Neurosci Lett 381: }\end{array}$ & I, II \\
& $289-293$
\end{tabular}

16 Li J, Xie W, Zhang JM, Baccei ML (2009) Peripheral nerve injury sensitizes neonatal dorsal horn neurons to tumor necrosis factoralpha. Mol Pain 5:10

17 Lindenlaub T, Sommer C (2003) Cytokines in V sural nerve biopsies from inflammatory and non-inflammatory neuropathies. Acta Neuropathol 105:593-602

Liu B, Li H, Brull SJ, Zhang JM (2002) IV Increased sensitivity of sensory neurons to tumor necrosis factor alpha in rats with chronic compression of the lumbar ganglia. J Neurophysiol 88:1393-1399

Liu YL, Zhou LJ, Hu NW et al. (2007) Tumor I, IV necrosis factor-alpha induces long-term potentiation of C-fiber evoked field potentials in spinal dorsal horn in rats with nerve injury: the role of NF-kappa B, JNK and p38 MAPK. Neuropharmacology 52:708-715

20 Lu VB, Biggs JE, Stebbing MJ, et al. (2009) Brain-derived neurotrophic factor drives the changes in excitatory synaptic transmission in the rat superficial dorsal horn that follow sciatic nerve injury. J Physiol 587:1013-1032

Ma W, Quirion R (2001) Increased phosphorylation of cyclic AMP response element-binding protein (CREB) in the superficial dorsal horn neurons following partial sciatic nerve ligation. Pain 93:295-301

22 Maione S, Siniscalco D, Galderisi U et al. (2002) Apoptotic genes expression in the lumbar dorsal horn in a model neuropathic pain in rat. Neuroreport 13:101-106

Marchand F, Tsantoulas C, Singh D et al. (2009) Effects of Etanercept and Minocycline in a rat model of spinal cord injury. Eur J Pain 13:673-681

Milligan ED, Twining C, Chacur $\mathrm{M}$ et al. (2003) Spinal glia and proinflammatory cytokines mediate mirror-image neuropathic pain in rats. J Neurosci 23:1026-1040

Moore KA, Kohno T, Karchewski LA et al. (2002) Partial peripheral nerve injury promotes a selective loss of GABAergic inhibition in the superficial dorsal horn of the spinal cord. J Neurosci 22:6724-6731

26 Murata Y, Nannmark U, Rydevik B et al. (2008) The role of tumor necrosis factoralpha in apoptosis of dorsal root ganglion cells induced by herniated nucleus pulposus in rats. Spine 33:155-162
Appendix continued

\begin{tabular}{lll}
\hline $\begin{array}{l}\text { Study } \\
\text { No. }\end{array}$ & Reference & $\begin{array}{l}\text { Exclusion } \\
\text { reason }\end{array}$ \\
\hline 27 & $\begin{array}{l}\text { Murata Y, Olmarker K, Takahashi I et al. } \\
\text { (2005) Effects of selective tumor necrosis } \\
\text { factor-alpha inhibition to pain-behavioral } \\
\text { changes caused by nucleus pulposus-induced } \\
\text { damage to the spinal nerve in rats. Neurosci }\end{array}$ & I \\
& $\begin{array}{l}\text { Lett 382:148-152 } \\
\text { Murata Y, Rydevik B, Takahashi K et al. }\end{array}$ & II
\end{tabular}
(2005) Incision of the intervertebral disc induces disintegration and increases permeability of the dorsal root ganglion capsule. Spine 30:1712-1716

29 Peng XM, Zhou ZG, Glorioso JC, Fink DJ, VI Mata M (2006) Tumor necrosis factor-alpha contributes to below-level neuropathic pain after spinal cord injury. Ann Neurol 59:843-851

30 Polgár E, Hughes DI, Arham AZ et al. (2005) II Loss of neurons from laminas I-III of the spinal dorsal horn is not required for development of tactile allodynia in the spared nerve injury model of neuropathic pain. J Neurosci 25:6658-6666

31 Schäfers M, Sommer C, Geis C et al. (2008) I Selective stimulation of either tumor necrosis factor receptor differentially induces pain behavior in vivo and ectopic activity in sensory neurons in vitro. Neuroscience 157:414-423

32 Scholz J, Broom DC, Youn DH et al. (2005) Blocking caspase activity prevents transsynaptic neuronal apoptosis and the loss of inhibition in lamina II of the dorsal horn after peripheral nerve injury. J Neurosci 25:7317-7323

33 Singh OV, Yaster M, Xu JT, Guan Y, Guan X, II Dharmarajan AM et al. (2009) Proteome of synaptosome-associated proteins in spinal cord dorsal horn after peripheral nerve injury. Proteomics 9:1241-1253

34 Siniscalco D, Fuccio C, Giordano C et al. II (2007) Role of reactive oxygen species and spinal cord apoptotic genes in the development of neuropathic pain. Pharmacol Res 55:158-166

35 Sommer C, Schmidt C, George A (1998) III Hyperalgesia in experimental neuropathy is dependent on the TNF receptor 1. Exp Neurol 151:138-142

36 Spengler RN, Sud R, Knight PR et al. (2007) Antinociception mediated by alpha(2)adrenergic activation involves increasing tumor necrosis factor alpha (TNFalpha) expression and restoring TNFalpha and alpha(2)-adrenergic inhibition of norepinephrine release. Neuropharmacology 52:576-589 
Appendix continued

\begin{tabular}{|c|c|c|}
\hline $\begin{array}{l}\text { Study } \\
\text { No. }\end{array}$ & Reference & $\begin{array}{l}\text { Exclusion } \\
\text { reason }\end{array}$ \\
\hline 37 & $\begin{array}{l}\text { Sud R, Ignatowski TA, Lo CP, Spengler RN } \\
\text { (2007) Uncovering molecular elements of } \\
\text { brain-body communication during } \\
\text { development and treatment of neuropathic } \\
\text { pain. Brain Behav Immun } 21: 112-124\end{array}$ & II \\
\hline 38 & $\begin{array}{l}\text { Yamashita M, Ohtori S, Koshi T et al. (2008) } \\
\text { Tumor necrosis factor-alpha in the nucleus } \\
\text { pulposus mediates radicular pain, but not } \\
\text { increase of inflammatory peptide, associated } \\
\text { with nerve damage in mice. Spine } \\
\text { 33:1836-1842 }\end{array}$ & I \\
\hline 39 & $\begin{array}{l}\text { Yang L, Zhang FX, Huang F et al. (2004) } \\
\text { Peripheral nerve injury induces trans-synaptic } \\
\text { modification of channels, receptors and signal } \\
\text { pathways in rat dorsal spinal cord. Eur J } \\
\text { Neurosci 19:871-883 }\end{array}$ & II \\
\hline 40 & $\begin{array}{l}\text { Youn DH, Wang H, Jeong SJ (2008) } \\
\text { Exogenous tumor necrosis factor-alpha } \\
\text { rapidly alters synaptic and sensory } \\
\text { transmission in the adult rat spinal cord dorsal } \\
\text { horn. J Neurosci Res } 86: 2867-2875\end{array}$ & IV \\
\hline
\end{tabular}

$I$ No TNF- $\alpha$ levels measurement, II TNF- $\alpha$ was not involved in inflammatory response, III outdated for the limits of this review; older than 10 years, $I V$ use of TNF- $\alpha$ as inductor of the lesion or inflammatory procedure, $V$ clinical study, $V I$ direct central nervous system injury

\section{References}

1. Gracely RH, Lynch SA, Bennett GJ (1992) Painful neuropathy: altered central processing maintained dynamically by peripheral input. Pain 51:175-194

2. Woolf CJ, King AE (1990) Dynamic alterations in the cutaneous mechanoreceptive fields of dorsal horn neurons in the rat spinal cord. J Neurosci 10:2717-2726

3. Woolf CJ, Wall PD (1986) The relative effectiveness of C primary afferent fibres of different origins in evoking a prolonged facilitation of the flexor reflex in the rat. J Neurosci 6:1433-1443

4. Ma QP, Woolf CJ (1996) Progressive tactile hypersensitivity: an inflammation-induced incremental increase in the excitability of the spinal cord. Pain 67:97-106

5. Morgan MJ, Kim YS, Liu ZG (2008) TNF alpha and reactive oxygen species in necrotic cell death. Cell Res 18:343-349

6. Bennett GJ, Xie YK (1988) A peripheral mononeuropathy in rat that produces disorders of pain sensation like those seen in man. Pain 33:87-107

7. Kim SH, Chung JM (1992) An experimental model for peripheral neuropathy produced by segmental spinal nerve ligation in the rat. Pain 50:355-363

8. Massie JB, Huang B, Malkmus S, Yaksh TL, Kim CW, Garfin SR, Akeson WH (2004) A preclinical post laminectomy rat model mimics the human post laminectomy syndrome. J Neurosci Methods 137:283-289

9. Olmarker K, Størkson R, Berge OG (2002) Pathogenesis of sciatic pain: a study of spontaneous behavior in rats exposed to experimental disc herniation. Spine 27:1312-1317

10. Rodrigues-Filho R, Campos MM, Ferreira J, Santos AR, Bertelli JA, Calixto JB (2004) Pharmacological characterisation of the rat brachial plexus avulsion model of neuropathic pain. Brain Res 1018:159-170

11. Seltzer Z, Dubner R, Shir Y (1990) A novel behavioral model of neuropathic pain disorders produced in rats by partial sciatic nerve injury. Pain 43:205-218

12. Song XJ, Hu SJ, Greenquist KW, Zhang JM, LaMotte RH (1999) Mechanical and thermal hyperalgesia and ectopic neuronal discharge after chronic compression of dorsal root ganglia. J Neurophysiol 82:3347-3358

13. Cope A, Ettinger R, McDevitt H (1997) The role of TNF-alpha and related cytokines in the development and function of the autoreactive T-cell repertoire. Res Immunol 148:307-312

14. Kim YS, Morgan MJ, Choksi S, Liu ZG (2007) TNF-induced activation of the Nox1 NADPH oxidase and its role in the induction of necrotic cell death. Mol Cell 26:675-687

15. Sakon S, Xue X, Takekawa M, Sasazuki T, Okazaki T, Kojima Y, Piao JH, Yagita H, Okumura K, Doi T, Nakano H (2003) NF-kappaB inhibits TNF-induced accumulation of ROS that mediate prolonged MAPK activation and necrotic cell death. EMBO J 22:3898-3909

16. Lee SC, Liu W, Dickson DW, Brosnan CF, Berman JW (1993) Cytokine production by human fetal microglia and astrocytes. Differential induction by lipopolysaccharide and IL-1 beta. J Immunol 150:2659-2667

17. McCoy MK, Tansey MG (2008) TNF signaling inhibition in the CNS: implications for normal brain function and neurodegenerative disease. J Neuroinflammation 5:45

18. Sawada M, Kondo N, Suzumura A, Marunouchi T (1989) Production of tumor necrosis factor-alpha by microglia and astrocytes in culture. Brain Res 491:394-397

19. Inoue K (2006) The function of microglia through purinergic receptors: neuropathic pain and cytokine release. Pharmacol Ther 109:210-226

20. Kreutzberg GW (1996) Microglia: a sensor for pathological events in the CNS. Trends Neurosci 19:312-318

21. Liu B, Hong JS (2003) Role of microglia in inflammation-mediated neurodegenerative diseases: mechanisms and strategies for therapeutic intervention. J Pharmacol Exp Ther 304:1-7

22. Si Q, Zhao ML, Morgan AC, Brosnan CF, Lee SC (2004) 15-deoxy-Delta12, 14-prostaglandin J2 inhibits IFN-inducible protein 10/CXC chemokine ligand 10 expression in human microglia: mechanisms and implications. J Immunol 173:35043513

23. Stoll G, Jander S (1999) The role of microglia and macrophages in the pathophysiology of the CNS. Prog Neurobiol 58:233-247

24. Hide I, Tanaka M, Inoue A, Nakajima K, Kohsaka S, Inoue K, Nakata Y (2000) Extracellular ATP triggers tumor necrosis factor-alpha release from rat microglia. J Neurochem 75:965-972

25. Inoue K, Tsuda M (2009) Microglia and neuropathic pain. Glia 57:1469-1479

26. Suzuki T, Hide I, Ido K, Kohsaka S, Inoue K, Nakata Y (2004) Production and release of neuroprotective tumor necrosis factor by P2X7 receptor-activated microglia. J Neurosci $24: 1-7$

27. Carpentier I, Coornaert B, Beyaert R (2004) Function and regulation of tumor necrosis factor type 2. Curr Med Chem 11:2205-2212

28. Faustman D, Davis M (2010) TNF receptor 2 pathway: drug target for autoimmune diseases. Nat Rev Drug Discov 9:482-493

29. Chen G, Goeddel DV (2002) TNF-R1 signaling: a beautiful pathway. Science 296:1634-1635

30. Lee KM, Jeon SM, Cho HJ (2009) Tumor necrosis factor receptor 1 induces interleukin-6 upregulation through NF-kappaB in a rat neuropathic pain model. Eur J Pain 13:794-806

31. MacEwan DJ (2002) TNF receptor subtype signalling: differences and cellular consequences. Cell Signal 14:477-492 
32. Arandjelovic S, Dragojlovic N, Li X, Myers RR, Campana WM, Gonias SL (2007) A derivative of the plasma protease inhibitor alpha(2)-macroglobulin regulates the response to peripheral nerve injury. J Neurochem 103:694-705

33. Bianchi M, Martucci C, Biella G, Ferrario P, Sacerdote P (2004) Increased substance $\mathrm{P}$ and tumor necrosis factor-alpha level in the paws following formalin injection in rat tail. Brain Res 1019:255-258

34. Bianchi M, Martucci C, Ferrario P, Franchi S, Sacerdote P (2007) Increased tumor necrosis factor-alpha and prostaglandin E2 concentrations in the cerebrospinal fluid of rats with inflammatory hyperalgesia: the effects of analgesic drugs. Anesth Analg 104:949-954

35. Campana WM, Li X, Shubayev VI, Angert M, Cai K, Myers RR (2006) Erythropoietin reduces Schwann cell TNF-alpha, Wallerian degeneration and pain-related behaviors after peripheral nerve injury. Eur J Neurosci 23:617-626

36. Costa B, Trovato AE, Comelli F, Giagnoni G, Colleoni M (2007) The non-psychoactive cannabis constituent cannabidiol is an orally effective therapeutic agent in rat chronic inflammatory and neuropathic pain. Eur J Pharmacol 556:75-83

37. Covey WC, Ignatowski TA, Renauld AE, Knight PR, Nader ND, Spengler RN (2002) Expression of neuron-associated tumor necrosis factor alpha in the brain is increased during persistent pain. Reg Anesth Pain Med 27:357-366

38. Dubový P, Jancálek R, Klusáková I, Svízenská I, Pejchalová K (2006) Intra- and extraneuronal changes of immunofluorescence staining for TNF-alpha and TNFR1 in the dorsal root ganglia of rat peripheral neuropathic pain models. Cell Mol Neurobiol 26:1205-1217

39. Elliott MB, Barr AE, Clark BD, Amin M, Amin S, Barbe MF (2009) High force reaching task induces widespread inflammation, increased spinal cord neurochemicals and neuropathic pain. Neuroscience 158:922-931

40. George A, Schmidt C, Weishaupt A, Toyka KV, Sommer C (1999) Serial determination of tumor necrosis factor-alpha content in rat sciatic nerve after chronic constriction injury. Exp Neurol 160:124-132

41. George A, Buehl A, Sommer C (2005) Tumor necrosis factor receptor 1 and 2 proteins are differentially regulated during Wallerian degeneration of mouse sciatic nerve. Exp Neurol 192:163-166

42. Hatashita S, Sekiguchi M, Kobayashi H, Konno S, Kikuchi S (2008) Contralateral neuropathic pain and neuropathology in dorsal root ganglion and spinal cord following hemilateral nerve injury in rats. Spine 33:1344-1351

43. Hayashi R, Xiao W, Kawamoto M, Yuge O, Bennett GJ (2008) Systemic glucocorticoid therapy reduces pain and the number of endoneurial tumor necrosis factor-alpha (TNFalpha)-positive mast cells in rats with a painful peripheral neuropathy. J Pharmacol Sci 106:559-565

44. Holmes GM, Hebert SL, Rogers RC, Hermann GE (2004) Immunocytochemical localization of TNF type 1 and type 2 receptors in the rat spinal cord. Brain Res 1025:210-219

45. Kato K, Kikuchi S, Shubayev VI, Myers RR (2009) Distribution and tumor necrosis factor-alpha isoform binding specificity of locally administered etanercept into injured and uninjured rat sciatic nerve. Neuroscience 160:492-500

46. Kleinschnitz C, Brinkhoff J, Sommer C, Stoll G (2005) Contralateral cytokine gene induction after peripheral nerve lesions: dependence on the mode of injury and NMDA receptor signaling. Mol Brain Res 136:23-28

47. Lee HL, Lee KM, Son SJ, Hwang SH, Cho HJ (2004) Temporal expression of cytokines and their receptors mRNAs in a neuropathic pain model. Neuroreport 15:2807-2811
48. Li X, Wang J, Wang Z, Dong C, Dong X, Jing Y, Yuan Y, Fan G (2008) Tumor necrosis factor-alpha of Red nucleus involved in the development of neuropathic allodynia. Brain Res Bull 77:233-236

49. Murata Y, Onda A, Rydevik B, Takahashi K, Olmarker K (2004) Distribution and appearance of tumor necrosis factor-alpha in the dorsal root ganglion exposed to experimental disc herniation in rats. Spine 29:2235-2241

50. Murata Y, Onda A, Rydevik B, Takahashi K, Olmarker K (2004) Selective inhibition of tumor necrosis factor-alpha prevents nucleus pulposus-induced histologic changes in the dorsal root ganglion. Spine 29:2477-2484

51. Murata Y, Nannmark U, Rydevik B, Takahashi K, Olmarker K (2006) Nucleus pulposus-induced apoptosis in dorsal root ganglion following experimental disc herniation in rats. Spine 31:382-390

52. Ohtori S, Takahashi K, Moriya H, Myers RR (2004) TNF-alpha and TNF-alpha receptor type 1 upregulation in glia and neurons after peripheral nerve injury: studies in murine DRG and spinal cord. Spine 29:1082-1088

53. Okamoto K, Martin DP, Schmelzer JD, Mitsui Y, Low PA (2001) Pro- and anti-inflammatory cytokine gene expression in rat sciatic nerve chronic constriction injury model of neuropathic pain. Exp Neurol 169:386-391

54. Otoshi K, Kikuchi S, Konno S, Sekiguchi M (2010) The reactions of glial cells and endoneurial macrophages in the dorsal root ganglion and their contribution to pain-related behavior after application of nucleus pulposus onto the nerve root in rats. Spine 35:264-271

55. Raghavendra V, Rutkowski MD, DeLeo JA (2002) The role of spinal neuroimmune activation in morphine tolerance/hyperalgesia in neuropathic and sham-operated rats. J Neurosci 22:9980-9989

56. Sacerdote $\mathrm{P}$, Franchi $\mathrm{S}$, Trovato AE, Valsecchi AE, Panerai AE, Colleoni M (2008) Transient early expression of TNF-alpha in sciatic nerve and dorsal root ganglia in a mouse model of painful peripheral neuropathy. Neurosci Lett 436:210-213

57. Sakuma Y, Ohtori S, Miyagi M, Ishikawa T, Inoue G, Doya H, Koshi T, Ito T, Yamashita M, Yamauchi K, Suzuki M, Moriya H, Takahashi K (2007) Up-regulation of p55 TNF alpha-receptor in dorsal root ganglia neurons following lumbar facet joint injury in rats. Eur Spine J 16:1273-1278

58. Schäfers M, Brinkhoff J, Neukirchen S, Marziniak M, Sommer C (2001) Combined epineurial therapy with neutralizing antibodies to tumor necrosis factor-alpha and interleukin-1 receptor has an additive effect in reducing neuropathic pain in mice. Neurosci Lett 310:113-116

59. Schäfers M, Sorkin LS, Geis C, Shubayev VI (2003) Spinal nerve ligation induces transient upregulation of tumor necrosis factor receptors 1 and 2 in injured and adjacent uninjured dorsal root ganglia in the rat. Neurosci Lett 347:179-182

60. Sekiguchi M, Sekiguchi Y, Konno S, Kobayashi H, Homma Y, Kikuchi S (2009) Comparison of neuropathic pain and neuronal apoptosis following nerve root or spinal nerve compression. Eur Spine J 18:1978-1985

61. Sweitzer S, Martin D, DeLeo JA (2001) Intrathecal interleukin-1 receptor antagonist in combination with soluble tumor necrosis factor receptor exhibits an anti-allodynic action in a rat model of neuropathic pain. Neuroscience 103:529-539

62. Uçeyler N, Tscharke A, Sommer C (2008) Early cytokine gene expression in mouse CNS after peripheral nerve lesion. Neurosci Lett 436:259-264

63. Vogel C, Stallforth S, Sommer C (2006) Altered pain behavior and regeneration after nerve injury in TNF receptor deficient mice. J Peripher Nerv Syst 11:294-303 
64. Xu JT, Xin WJ, Zang Y, Wu CY, Liu XG (2006) The role of tumor necrosis factor-alpha in the neuropathic pain induced by Lumbar 5 ventral root transection in rat. Pain 123:306-321

65. Homma Y, Brull SJ, Zhang JM (2002) A comparison of chronic pain behavior following local application of tumor necrosis factor alpha to the normal and mechanically compressed lumbar ganglia in the rat. Pain 95:239-246

66. Marchand F, Tsantoulas C, Singh D, Grist J, Clark AK, Bradbury EJ, McMahon SB (2009) Effects of Etanercept and Minocycline in a rat model of spinal cord injury. Eur J Pain 13:673-681

67. Murata Y, Onda A, Rydevik B, Takahashi I, Takahashi K, Olmarker K (2006) Changes in pain behavior and histologic changes caused by application of tumor necrosis factor-alpha to the dorsal root ganglion in rats. Spine 31:530-535

68. Ozaktay AC, Kallakuri S, Takebayashi T, Cavanaugh JM, Asik I, DeLeo JA, Weinstein JN (2006) Effects of interleukin-1 beta, interleukin-6, and tumor necrosis factor on sensitivity of dorsal root ganglion and peripheral receptive fields in rats. Eur Spine $\mathbf{J}$ 15:1529-1537

69. Peng XM, Zhou ZG, Glorioso JC, Fink DJ, Mata M (2006) Tumor necrosis factor-alpha contributes to below-level neuropathic pain after spinal cord injury. Ann Neurol 59:843-851

70. Hermann GE, Hebert SL, Van Meter MJ, Holmes GM, Rogers RC (2004) TNF alpha-p55 receptors: medullary brainstem immunocytochemical localization in normal and vagus nervetransected rats. Brain Res 1004:156-166

71. Kawasaki Y, Zhang L, Cheng JK, Ji RR (2008) Cytokine mechanisms of central sensitization: distinct and overlapping role of interleukin-1beta, interleukin-6, and tumor necrosis factoralpha in regulating synaptic and neuronal activity in the superficial spinal cord. J Neurosci 28:5189-5194
72. Schäfers M, Sommer C, Geis C, Hagenacker T, Vandenabeele P, Sorkin LS (2008) Selective stimulation of either tumor necrosis factor receptor differentially induces pain behavior in vivo and ectopic activity in sensory neurons in vitro. Neuroscience 157:414-423

73. Youn DH, Wang H, Jeong SJ (2008) Exogenous tumor necrosis factor-alpha rapidly alters synaptic and sensory transmission in the adult rat spinal cord dorsal horn. J Neurosci Res 86:2867-2875

74. DeLeo JA, Rutkowski MD, Stalder AK, Campbell IL (2000) Transgenic expression of TNF by astrocytes increases mechanical allodynia in a mouse neuropathy model. Neuroreport 11:599-602

75. Yamashita M, Ohtori S, Koshi T, Inoue G, Yamauchi K, Suzuki M, Takahashi K (2008) Tumor necrosis factor-alpha in the nucleus pulposus mediates radicular pain, but not increase of inflammatory peptide, associated with nerve damage in mice. Spine 33:1836-1842

76. Zanella JM, Burright EN, Hildebrand K, Hobot C, Cox M, Christoferson L, McKay WF (2008) Effect of etanercept, a tumor necrosis factor-alpha inhibitor, on neuropathic pain in the rat chronic constriction injury model. Spine 33:227-234

77. Arnett HA, Mason J, Marino M, Suzuki K, Matsushima GK, Ting JP (2001) TNF alpha promotes proliferation of oligodendrocyte progenitors and remyelination. Nat Neurosci 4:1116-1122

78. Fontaine V, Mohand-Said S, Hanoteau N, Fuchs C, Pfizenmaier K, Eisel U (2002) Neurodegenerative and neuroprotective effects of tumor Necrosis factor (TNF) in retinal ischemia: opposite roles of TNF receptor 1 and TNF receptor 2. J Neurosci 22:RC216

79. Aggarwal BB (2003) Signalling pathways of the TNF superfamily: a double-edged sword. Nat Rev Immunol 3:745-756 